\title{
Assessment of Different Priming Methods on Germination and Seed Quality Parameters of Groundnut (Arachis hypogea L.)
}

\author{
S. Shafiya Mohammady ${ }^{{ }^{*}}$, Arun Kumar Chaurasia ${ }^{1}$, \\ D. Chinna Dasthagiri ${ }^{1}$ and C. H. Jyothsna ${ }^{2}$
}

${ }^{1}$ Department of Genetics and Plant Breeding, Naini Agricultural Institute, Sam Higginbottom University of Agriculture, Technology and Sciences, Prayagraj, U. P., India

${ }^{2}$ Director, State Institute for Management of Agriculture, Department of Agriculture, Govt. of Uttar Pradesh, India

*Corresponding author

\section{A B S T R A C T}

\begin{tabular}{|l|}
\hline Key w or d s \\
$\begin{array}{l}\text { Groundnut, Halo } \\
\text { priming and } \\
\text { Hormonal priming }\end{array}$ \\
\hline Article Info \\
\hline $\begin{array}{l}\text { Accepted: } \\
\text { 10 January } 2021 \\
\text { Available Online: } \\
\text { 10 February } 2021\end{array}$ \\
\hline
\end{tabular}

An investigation was carried out for Assessment of different priming methods on germination and seed quality parameters of groundnut (Arachis hypogea L.) genotype. The treatments were $\mathrm{T}_{0^{-}}$Control (un primed), $\mathrm{T}_{1^{-}} \mathrm{GA}_{3}(50 \mathrm{ppm}), \mathrm{T}_{2}-$ Salicylic acid (50 ppm), $\mathrm{T}_{3^{-}}$Mannitol (1\%), $\mathrm{T}_{4^{-}}$PEG (1\%), $\mathrm{T}_{5}$-Trichodermaviridae $(5 \mathrm{gm} / \mathrm{kg}), \mathrm{T}_{6^{-}}$Trichoderma harzianum $(5 \mathrm{gm} / \mathrm{kg}), \mathrm{T}_{7}$-Calcium chloride $(1 \%), \mathrm{T}_{8^{-}}$Coconut water $(5 \%), \mathrm{T}_{9^{-}}$ Garlic(Allium sativum) bulb extract (5\%), $\mathrm{T}_{10}$-Turmeric (Curcuma longa) Rhizome extract $(5 \%), \mathrm{T}_{11}$-Neem leaf extract $(5 \%)$, and $\mathrm{T}_{12}$-Vermiwash (5\%). The Analysis of variance under laboratory revealed that mean sum of squares due to seed priming treatments were significant for all the characters under study indicating presence of good amount of variability among the treatments for all the characters under study. Comparison of various treatments revealed that seed priming have significant role for all the characters studied under laboratory experiment. Application of $\mathrm{CaCl}_{2}(1 \%)$ and $\mathrm{GA}_{3}(50 \mathrm{ppm})$ was found significantly superior over control for the characters studied. Thus, priming with $\mathrm{CaCl}_{2}(1 \%)$ solution for 12 hours is advantageous to obtain healthy seedlings. The second best option for priming is priming with $\mathrm{GA}_{3}(50 \mathrm{ppm})$.

\section{Introduction}

Groundnut (Arachis hypogea L.) is an important oil seed crop and grain legume world wide (Mensah and Obadoni, 2007). It has originated in brazil and belongs to family Leguminosae and sub family papilionaceae and chromosome no $2 n=40$. The word groundnut is derived from two Greek words,
'Arachis' meaning a legume and 'hypogea', meaning below ground referring to the pods in the soil and occupied a significant position in the agricultural economy of the country.

Ground nut is also known as peanut, earthnut and manila nut. Among the oil seed crops, ground nut has first place in India. Ground nut oil is primarily used in the manufacture of 
vegetable oil (vanaspati ghee). Its seed contain about $45 \%$ oil and $26 \%$ protein. Ground nut kernel has a whole is highly digestible. It is in the first place as concentrated food as one gram supplies 5.8 food calories. The biological value of groundnut protein is among the highest of the vegetable proteins, and equals that of casein. Ground nuts are a good source of all B vitamins except $B_{12}$. They are a rich source of thiamine, riboflavin, nicotinic acid and vitamin $\mathrm{E}$. however, they lack in vitamin $\mathrm{A}$. With regard to minerals, phosphorus, calcium and iron are present in significant amount. The kernels are consumed either roasted or fried and salted (Singh, 1980).

Ground is commonly called as poor man's nut. It is characterized by cliestogamy and hence, it is highly self pollinated in nature (Knauft and Wynne, 1995).Groundnut is an important food and oil crop in tropical and sub tropical region. It is the world's fourth most important source of edible oil and third most important source of vegetable protein.

Groundnut contains on the average $12-15 \%$ carbohydrates, $25-30 \%$ protein and $45-50 \%$ oil. The nuts may be chewed uncooked, but are usually eaten boiled or roasted. The nuts can also be boiled, fried, ground into groundnut butter or crushed for oil. Groundnut butter is extensively used in the preparation of soup (Tsigbey et al., 2004).

The major groundnut producing countries in the world are India, China, Nigeria, Senegal, Sudan, Burma and the United States of America. Worldwide groundnut is grown in 26.4 million hectares with a total production of 37.1 million metric tonnes and average productivity of 1.4 metric $\mathrm{t} / \mathrm{ha}$ (GOI, New Delhi, 2008).

India has been one of the among the top three producing countries of groundnut in the world. It ranks second next to china. Nearly 16 percent of groundnut production is contributed by India to the world production during 2016. Groundnut crop is cultivated about 4.56 million hectares, with the total production of 6.77 million tonnes and with the average yield of $1486 \mathrm{~kg} /$ hectare. The area under groundnut constitutes approximately $3.3 \%$ of the net sown area in India (Gayatri, 2018).

Good quality seeds having rapid and uniform field emergence is an essential prerequisite for increase yield, quality and ultimately profit to farmers. Uniformity and percentage seedling emergence of direct seeded crops has major impact on final yield and quality. Slow emergence results in weaker seedlings which are more prone to diseases. Various pre sowing seed treatments have been practiced to reduce the time between sowing and seeding emergence. Heydecker (1973) acknowledged the term "seed priming" coined by Malnassy (1971) and showed the beneficial effect of priming. The term seed priming is synonymous with seed invigouration.

Seed priming is widely used now a day for betterment of seed performance in terms of higher rate of germination and uniformity of establishment. Also it causes the reduction in emergence time, accomplishment of uniform emergence and betterment of crop stand in many crops. More recently priming with a range of agents like hormones, botanicals, bio agents and growth regulators is under practice to get the desired benefits during seed germination and later on good performance of the crop (Janmohammadi et al., 2008).

Seed priming is technique which involves uptake of water by the seed followed by drying to initiate the early events of germination up to the point of radical emergence. Its benefits include rapid, uniform and increased germination, improved seedling 
vigour and growth under a broad range of environment resulting in better stand establishment and alleviation of phytochrome -induced dormancy. Seed priming is a presowing strategy for influencing seedling development by modulating pre-germination metabolic activity prior to emergence of radical and generally enhance germination rate and plant performance (Bradford, 1986; Tailor and Harman, 1990).

During priming, seeds are partially hydrated so that pre-germination metabolic activities proceed, while, radical protrusion is prevented, then are dried back to original moisture level (McDonald, 2000).

\section{Materials and Methods}

The Research study was conducted at Seed Testing Laboratory, Department of Genetics and Plant Breeding, Naini Agriculture Institute, Sam Higginbottom University of Agriculture, Technology and Sciences, Prayagraj during rabi-2019 to find out Assessment of different priming methods on germination and seed quality parameters of groundnut (Arachis hypogea L.). The data was collected on ten randomly selected healthy seedlings plants from each replication and different observations were recorded. In laboratory experiment data were recorded for 9 characters, viz., germination (\%), speed of germination, root length $(\mathrm{cm})$, shoot length $(\mathrm{cm})$, seedling length $(\mathrm{cm})$, seedling fresh weight (gm), seedling dry weight (gm), seedling vigour index $-\mathrm{I}$ and Seedling vigour index - II. The treatments were represented as $\mathrm{T}_{0}$ (Control), $\mathrm{T}_{1^{-}}$GA3 (50 ppm), $\mathrm{T}_{2}$ Salicylic acid (50 ppm), $\mathrm{T}_{3}-$ Mannitol (0.01), $\mathrm{T}_{4^{-}}$PEG (0.01), $\mathrm{T}_{5}$-Trichoderma viridae $(5 \mathrm{gm} / \mathrm{kg}), \quad \mathrm{T}_{6^{-}} \quad$ Trichoderma harzianum $(5 \mathrm{gm} / \mathrm{kg}), \mathrm{T}_{7}$-Calcium chloride $(0.01), \mathrm{T}_{8^{-}}$ Coconut water (0.05), $\mathrm{T}_{9-}$ Garlic (Allium sativum) bulb extract (0.05), $\mathrm{T}_{10}$-Turmaric (Curcuma longa) Rhizome extract (0.05), $\mathrm{T}_{11^{-}}$
Neem leaf extract $(0.05)$ and $\mathrm{T}_{12}$-Vermiwash (0.05).

\section{Preparation of solutions}

For preparation of $50 \mathrm{ppm} \mathrm{GA}_{3}$ solution, $50 \mathrm{mg}$ of $\mathrm{GA}_{3}$ was dissolved in $100 \mathrm{ml}$ of distilled water. The solution of salicylic acid was prepared by dissolving $50 \mathrm{mg}$ of salicylic acid in $100 \mathrm{ml}$ of distilled water. For preparation of mannitol, $\mathrm{Cacl}_{2}$ and PEG (1\%) $1 \mathrm{gm}$ of mannitol, $1 \mathrm{gm}$ of $\mathrm{Cacl}_{2}$ and $1 \mathrm{gm}$ of PEG was dissolved in $100 \mathrm{ml}$ of distilled water. The solution of Trichodema viridae $0.25 \mathrm{gm}$ and Trichodema harzianum $0.25 \mathrm{gm}$ was dissolved in $100 \mathrm{ml}$ of distilled water. The flasks containing chemicals were covered with muslin cloth to avoid any contamination.

For the preparation of botanicals like coconut water $5 \%$ coconut water solution $5 \mathrm{ml}$ of coconut water is dissolved in $100 \mathrm{ml}$ distilled water. Fresh garlic bulbs were washed in tap water, peeled and crushed into fine paste by using mortar and pistle. $5 \mathrm{ml}$ of the sample was ground by a blender with $100 \mathrm{ml}$ of distilled water.

For the preparation of turmeric extract and vermiwash $(5 \%) 5 \mathrm{gm}$ of turmeric powder was dissolved in $100 \mathrm{ml}$ of distilled water, 5 $\mathrm{ml}$ of vermiwash was dissolved in $100 \mathrm{ml}$ of distilled water. For the preparation of neem leaf extract $5 \mathrm{gm}$ of leaf powder was dissolved in $100 \mathrm{ml}$ distilled water to make $5 \%$ solution. To remove unwanted material and debris the leaf extracts were filtered using a muslin cloth.

After preparation of solutions, seeds were soaked in for a duration of $12 \mathrm{hr}$ and shade dried.

These seeds were used for further laboratory studies to record observations. 


\section{Results and Discussion}

It is evident from the present investigation that priming treatments has significant effect on quality parameters in groundnut. In general, most of the treatments have increased germination and vigour parameters as compared to control (untreated seeds). maximum seed germination \% $(88.5 \%)$, speed of germination $(69.85)$, root length $(13.19 \mathrm{~cm})$ and shoot length $(6.61 \mathrm{~cm})$, seedling fresh weight (39.98gm), seedling dry weight $(2.72 \mathrm{~g})$, seedling vigour index I (17623g), seedling vigour index II (227.72) was recorded in $\mathrm{T}_{7}$-Calcium chloride (1 per cent) followed by $\mathrm{T}_{8}$ - Coconut water $(5$ percent) . maximum seedling length $(\mathrm{cm})$ was recorded in $\mathrm{T}_{1}$ - GA3 $(50 \mathrm{ppm})(19.48 \mathrm{~cm})$. However, $\mathrm{T}_{0}$-Control being the lowest.
Similar results were observed by Hasan et al., (2005), MisrakKebede et al., (2015), Dileepkumar Masuthi et al., (2015), Cupcupin et al., Vinothni and Bhavyasree (2019).

From the present investigation It is concluded from the present investigation of seed treatments with different kind of priming exhibited significant effect on seed germination \%, speed of germination, root, shoot and seedling length, seedling fresh and dry weight and seed vigour index. Seed priming with $\mathrm{CaCl}_{2}(1 \%)$ affected all the lab parameters significantly in comparison to control and other priming treatments. Thus, priming with $\mathrm{CaCl}_{2}$ (1\%) solution for 12 hours is advantageous to obtain healthy seedlings (Table 1).

Table.1 Mean performance of seed quality parameters due to various priming treatments in groundnut

\begin{tabular}{|c|c|c|c|c|c|c|c|c|c|c|}
\hline $\begin{array}{l}\text { S. } \\
\text { no. }\end{array}$ & Treatments & $\begin{array}{c}\text { Germination } \\
\text { percentage }\end{array}$ & $\begin{array}{c}\text { Speed of } \\
\text { germination }\end{array}$ & $\begin{array}{c}\text { Root } \\
\text { length }\end{array}$ & $\begin{array}{c}\text { Shoot } \\
\text { length }\end{array}$ & $\begin{array}{c}\text { Seedling } \\
\text { length }\end{array}$ & $\begin{array}{c}\text { Seedling } \\
\text { fresh } \\
\text { weight }\end{array}$ & $\begin{array}{c}\text { Seedling } \\
\text { Dry } \\
\text { weight }\end{array}$ & $\begin{array}{c}\text { Seedling } \\
\text { Vigour } \\
\text { Index-I }\end{array}$ & $\begin{array}{c}\text { Seedling } \\
\text { vigour } \\
\text { Index-II }\end{array}$ \\
\hline $\mathbf{1}$ & $\mathbf{T}_{\mathbf{0}}$ & 79.50 & 32.88 & 10.04 & 2.73 & 12.53 & 23.15 & 1.96 & 10686.38 & 154.84 \\
\hline $\mathbf{2}$ & $\mathbf{T}_{\mathbf{1}}$ & 84.25 & 61.83 & 9.51 & 6.36 & 19.48 & 34.20 & 2.41 & 14481.13 & 207.24 \\
\hline $\mathbf{3}$ & $\mathbf{T}_{\mathbf{2}}$ & 83.00 & 44.10 & 9.46 & 6.55 & 16.19 & 34.33 & 2.62 & 14853.00 & 216.32 \\
\hline $\mathbf{4}$ & $\mathbf{T}_{\mathbf{3}}$ & 86.50 & 45.33 & 10.98 & 5.21 & 16.40 & 32.20 & 2.43 & 15327.25 & 209.03 \\
\hline $\mathbf{5}$ & $\mathbf{T}_{\mathbf{4}}$ & 83.50 & 45.18 & 8.88 & 5.16 & 14.23 & 30.20 & 2.51 & 13414.25 & 208.68 \\
\hline $\mathbf{6}$ & $\mathbf{T}_{\mathbf{5}}$ & 85.75 & 45.50 & 11.01 & 6.28 & 16.00 & 35.33 & 2.31 & 16840.13 & 196.17 \\
\hline $\mathbf{7}$ & $\mathbf{T}_{\mathbf{6}}$ & 85.25 & 43.00 & 9.85 & 6.58 & 16.56 & 30.13 & 2.21 & 14954.63 & 188.14 \\
\hline $\mathbf{8}$ & $\mathbf{T}_{\mathbf{7}}$ & 88.50 & 69.85 & 13.19 & 6.61 & 17.81 & 39.98 & 2.72 & 17623.00 & 227.72 \\
\hline $\mathbf{9}$ & $\mathbf{T}_{\mathbf{8}}$ & 87.00 & 48.55 & 10.03 & 6.45 & 16.64 & 36.78 & 2.47 & 10904.13 & 212.19 \\
\hline $\mathbf{1 0}$ & $\mathbf{T}_{\mathbf{9}}$ & 86.50 & 46.03 & 9.44 & 6.58 & 16.36 & 36.68 & 2.42 & 15669.88 & 212.51 \\
\hline $\mathbf{1 1}$ & $\mathbf{T}_{\mathbf{1 0}}$ & 86.75 & 49.08 & 10.56 & 5.59 & 15.90 & 25.28 & 2.28 & 14439.75 & 195.74 \\
\hline $\mathbf{1 2}$ & $\mathbf{T}_{\mathbf{1 1}}$ & 86.00 & 42.58 & 10.29 & 5.71 & 15.69 & 30.33 & 2.12 & 14677.20 & 181.23 \\
\hline $\mathbf{1 3}$ & $\mathbf{T}_{\mathbf{1 2}}$ & 86.00 & 47.25 & 10.38 & 5.06 & 15.76 & 27.63 & 2.20 & 14738.38 & 187.61 \\
\hline Grand $\mathbf{m e a n}$ & 85.27 & 47.78 & 10.28 & 5.76 & 16.12 & 32.01 & 2.36 & 14508.39 & 199.8 \\
\hline & $\mathbf{C . D .}$ & 4.45 & 6.01 & 2.04 & 1.25 & 2.73 & 6.23 & 0.38 & 3357.32 & 32.1 \\
\hline & SE(m) & 1.56 & 2.10 & 0.72 & 0.44 & 0.96 & 2.18 & 0.13 & 1173.67 & 11.22 \\
\hline & SE(d) & 2.2 & 2.97 & 1.01 & 0.62 & 1.35 & 3.08 & 0.19 & 1659.83 & 15.87 \\
\hline & $\mathbf{C . V}$ & 3.65 & 8.78 & 13.93 & 15.33 & 11.87 & 13.61 & 11.21 & 16.18 & 11.23 \\
\hline
\end{tabular}




\section{References}

Ajirloo, A. R., Shaban, M., and Moghanloo, G. D. (2013). Effect of priming methods on emergence and seedling growth of maize (Zea mays L.). International Journal of Farming and Allied Sciences, 2, 658-661.

Arif, M.T. Jan, B.K. Marwat and Khan, A.M. 2008. Seed priming improves emergence and yield of soybean. Pakistan J. Bot. 40(3):1169-1177.

Inayat- Ur- Rahmanet al., (2016). Effect of seed priming on germination performance and yield of okra (Abelmoschus esculentus L.).

Sanoj Kumar et al., (2017). Effect of seed treatments with botanical, chemical, on the yield and quality traits in groundnut (Arachis hypogea L.). Journal of Pharmacognosy and Phytochemistry, 6(4): 10-13.

Sharma et al., (2014). Comparison of various seed priming methods for germination, seedling vigour and fruit yield in okra (Abelmoschus esculntus L. monech). Scientia Horticulture; 165:75-81.

Srivastava AK, Lokhande VH, PatadeVYwx, Suprasanna P, Sjahril R, D’Souza SF (2010).Comparative evaluation of hydro-, chemo-, and hormonal priming methods for imparting salt and PEG stress tolerance in Indian mustard (Brassica juncea L.). Acta Physiologiae Plantarum. 2010; 32: 1135-44. 10.1007/s11738-010-0505-y.

Patel J.B., Anita Oketa and FabianApaa (2016).Effect of plant growth regulators on plant growth, yield and its components in brinjal. AGRES-An International e-Journal, (2016) Vol.5, Issue 1: 1-12.

Rai, N. and Bansiwal, K., (2008). Vermiwash: an excellent source of nutrition for plant growth. Electronic Journal of Environmental Sciences. 1: 19-21.
Ramana,V,Ramakrishna,M,Purushotham,Kan dBalakrishnaReddy,K.(2010). Effect of bio-fertilizers on growth, yield attributes and yield of french bean (Phaseolus vulgaris L.). Legume Res., 33 (3): 178 - 183, 2010.

Rathod, R.R., Gore, R.V, and Bothikar, P. (2015). Effect of Growth Regulators on Growth and Yield of French bean (Phaseolus vulgaris L.) Var. ArkaKomal. OSR Journal of Agriculture and Veterinary Science (IOSR-JAVS) e-ISSN: 2319-2380, pISSN: 2319-2372. Volume 8, Issue 5 Ver. I.

RK Yadav et al., (2018).Techniques of seed priming in field crops. International Journal of Chemical Studies. 6(3): 1588-1594.

Sanoj Kumar et al., (2017). Effect of seed treatments with botanical, chemical, on the yield and quality traits in groundnut (Arachis hypogea L.). Journal of Pharmacognosy and Phytochemistry; 6(4): 10-13.

Sharma et al., (2014). Comparison of various seed priming methods for germination, seedling vigour and fruit yield in okra (Abelmoschus esculntus L. monech). Scientia Horticulture; 165:75-81.

Srivastava AK, Lokhande VH, PatadeVYwx, Suprasanna P, Sjahril R, D'Souza SF (2010).Comparative evaluation of hydro-, chemo-, and hormonal priming methods for imparting salt and PEG stress tolerances in Indian mustard (Brassica juncea L.). Acta Physiologiae Plantarum. 2010; 32: 1135-44. 10.1007/s11738-010-0505-y.

Stephen K. et al., (2018).Optimizing priming concentration and duration of various priming agents for improved seed germination in chilli (Capsicum annum L.).Journal of Pharmacognosy and Phytochemistry; 7(4): 2689-2693.

Suresh Babu S. Dr. B. S. Janagoudar 
MajoAdvisor., (2005). Effects of seed priming with plant growth regulators and micronutrients on growth and yield of cotton (Gossypium herbaceum L.). under salinity stress. Journal of Applied Microbiology.105:170-1177.

\section{How to cite this article:}

Shafiya Mohammady, S., Arun Kumar Chaurasia, D. Chinna Dasthagiri and Jyothsna, CH. 2021. Assessment of Different Priming Methods on Germination and Seed Quality Parameters of Groundnut (Arachis hypogeal L.). Int.J.Curr.Microbiol.App.Sci. 10(02): 1061-1066. doi: https://doi.org/10.20546/ijcmas.2021.1002.125 